\title{
Emerging hematological targets and therapy for cardiovascular disease: From bench to bedside
}

\author{
Ana Villegas \\ Fernando A Gonzalez \\ Leopoldo Llorente \\ Santiago Redondo \\ Service of Hematology \\ and Hemotherapy, Hospital \\ Clinico Universitario \\ San Carlos, Madrid, Spain
}

Correspondence: Santiago Redondo Service of Hematology and Hemotherapy, Hospital Clinico Universitario San Carlos, Prof. Martin Lagos s/n, 28040 Madrid, Spain Tel +34 9 I330 332 I

Email santiredondo@hotmail.com

\begin{abstract}
Atherosclerotic cardiovascular disease is the leading cause of death and a major part of its pathophysiology remains obscure. Some hematological targets have been related to the development and clinical outcome of this disease, especially soluble cytokines, leukocytes, red blood cells, hemostatic factors and platelets, and bone-marrow vascular progenitors. These emerging factors may be modulated by current antiatherosclerotic pharmacotherapy, target-designed novel drugs or progenitor cell therapy. The aim of current review article is to comprehensively review the role of these antiatherosclerotic targets and therapy.
\end{abstract}

Keywords: atherosclerosis, blood, progenitor cells, cytokines, therapy

\section{Emerging hematological targets for cardiovascular disease}

\section{Historical development}

Cardiovascular disease is the leading cause of death and disability (Ezzati et al 2005). In the last years of the 20th century the role of inflammation in atherosclerosis was widely recognized (Ross et al 1999), according to previous hypotheses (Virchow 1858).

Nevertheless, a mere tissue and innate immunity-mediated response to local inflammation did not fit several observations. First was the coincidence of different atherosclerotic locations (coronary, aortic, carotid), at a simultaneous degree of evolutionary state (Helft et al 2002). Second was the the growing concern of accelerated atherosclerosis in autoimmune diseases (Shoenfeld et al 2005), which highlighted the importance of acquired immunity in this vascular disorder (Hansson and Libby 2006). The third event was the discovery of bone-marrow derived progenitor cells that were able to differentiate towards the endothelial lineage in animal models (Asahara et al 1997) and humans (Vasa et al 2001a), being the medical importance of these progenitors an emerging matter of interest (Hristov et al 2003).

\section{Soluble inflammatory mediators in atherosclerosis}

The approach of atherosclerosis as an inflammatory disease led to the search of inflammatory markers (reviewed in Table 1). Several of these molecules include: interleukin (IL)-1 (Ikonomidis et al 1999), IL-ra (Rothenbacher et al 2005), tumor necrosis factor (TNF) (Naya et al 2007), IL-6 (Langenberg et al 2006), and monocyte chemotactic protein-1 (MCP-1) (Hoogeven et al 2005). However, although these markers seem to be elevated in atherosclerotic patients compared to disease-free controls, their lack of specificity seems to be the most important limitation.

In atherosclerosis, a misbalance between T-helper-1/T-helper-2 (Th1/Th2) function seems to take place (Szodoray 2006). Th1 function (mediated by the cytokines interferon (IF)- $\gamma$, TNF- $\alpha$ ) is regarded as proatherogenic, whereas Th2 (mediated by IL-4, IL-5) 
Table I Inflammatory factors at the vessel wall level

\begin{tabular}{l} 
Molecule \\
\hline IL-I Initiator of cell adhesion molecule expression \\
IL-ra IL-I receptor antagonist (soluble endogenous inhibitor) \\
MCP-I Monocytic chemo-attracting protein \\
TNF- $\alpha$ Induces cell apoptosis, inflammation, and adhesion \\
IL-6 Soluble trigger for hepatic CRP release \\
IF- $\gamma$ Interferon gamma, macrophage stimulus \\
IL-4 and 5 Typical Th2 cytokines \\
IL-I0 Th2 inducer \\
TGF- $\beta$ I Modulates inflammation, cell growth and differentiation \\
CRP C-reactive protein, induces endothelium activation \\
CD36 Stimulus for cholesterol uptake and foam cell transformation \\
HSP65 Heat shock protein, initiator of intracellular inflammation \\
SDF Induces stem and inflammatory cell adhesion/migration \\
CXCR4 Chemokine family receptor for SDF \\
PDGF Potent mitogenic factor for vascular smooth muscle
\end{tabular}

Abbreviations: CRP, C-reactive protein; IF, interferon; IL, interleukin; TGF, tumor growth factor; TNF, tumor necrosis factor; PDGF, platelet-derived growth factor; SDF, stromal-derived factor.

is considered as protective (Hansson and Robertson 2004). Balance is mediated by Th3 function, which may regulate transition from Th1 to Th2 by the cytokines IL-10 and tumor growth factor (TGF)- $\beta 1$ (Redondo et al 2007a). However, although serum levels of active and total fraction of TGF$\beta 1$ have been related to both the protection against an acute coronary event (Grainger et al 1995) and the development of chronic atherosclerosis lesions (Laviades et al 2000), the implementation of blood levels of TGF- $\beta 1$ for atherosclerosis diagnosis has remained elusive (Redondo et al 2007a).

Among all biochemical blood inflammatory markers for atherosclerosis, C-reactive protein (CRP) has been studied deeply (Ridker 2003). This protein is secreted by the liver in response to serum IL-6 and activated from pentameric to monomeric on the vessel wall, where it enhances inflammatory cell recruitment, platelet adhesion and thrombosis (Khreiss et al 2004). Large clinical evidence linked blood levels of high-sensitivity measured $\mathrm{CRP}$ as an independent marker for subclinical atherosclerosis (Thakore et al 2007), cardiovascular disease severity (Bansal and Ridker 2007), and the coming of future cardiovascular events (Blake et al 2003; Bansal and Ridker 2007). However, more recent clinical evidence subsequently showed the limitations of this marker as an independent risk factor (Fortmann et al 2004; Wilson et al 2005; Lloyd-Jones et al 2006).

\section{Leukocytes}

White cell count has been established as an independent marker of subclinical atherosclerosis (Sen et al 2007).
Moreover, this widely available parameter may be a sensitive predictor of the coming of future coronary events (Haim et al 2004) and long-term mortality (Núñez et al 2005).

The role of leukocytes in atherosclerosis was first recognized for the monocyte/macrophage lineage. Pathologic specimens have always shown the accumulation of macrophages in the extreme zone of atherosclerotic lesions (the plaque shoulder), which make them more prone to rupture and thrombosis (Fuster et al 2005). These inflammatory macrophages are positive for $\mathrm{CD}^{2} 6^{+}$, a scavenger receptor which facilitates the uptake of small and dense oxidized low-density lipoprotein (LDL) particles and gives them the appearance of foam cells (Martin-Fuentes et al 2007). These foam cells become inflammatory enhancers, which precipitate the plaque instability (Kuchibhotla et al 2008). Circulating monocytes, the blood precursors of macrophages, have also been implicated in atherosclerosis. Clinical whole monocyte count precedes the coming of coronary (Madjid et al 2004) and cerebrovascular (Johnsen et al 2005) events, as well as subclinical carotid stenosis (Chapman et al 2004). Moreover, a direct correlation has been found for monocyte count and infarct size (Meisel et al 1998). Monocyte concentration has equally been inversely correlated to eventual ejection fraction after ischemia (Maekawa et al 2002). After coronary artery bypass grafting these monocytes lose the membrane receptor $\mathrm{CD} 14^{+}$and secrete soluble CD14 to plasma, a general mechanism in monocyte activation (Fingerle-Rowson 1998).

Another leukocyte type with emerging importance in atherosclerosis is the lymphocyte, since a significant accumulation of lymphocytes has been reported in histological studies (Fuster et al 2005). They are mostly T cells $\left(\mathrm{CD}^{+}\right)$, with helper function $\left(\mathrm{CD}^{+}\right)$which participate in plaque instability by secretion of cytokines, specially associated with the Th1 phenotype (Hansson and Robertson 2006). In order to regulate this atherogenic immune response, several experimental attempts in animal models have been made with vaccines to induce antibodies secretion and further elimination of oxidized LDL (Binder et al 2003), or immunological tolerance for HSP65 (Harats et al 2002).

An increasing amount of experimental and clinical evidence highlights the importance of neutrophils in atherosclerosis. Neutrophils have been shown to predict clinical coronary stenosis (Avanzas et al 2004). These clinical observations have been reproduced in experimental conditions. In the apoE-/- mice model, disruption of the SDF/ CXCR4 by the drug AMD3100 increased bone marrow production, blood levels and atherosclerotic infiltration of 
neutrophils, an event which was able to be prevented by anti-neutrophil antibody injection (Zernecke et al 2008).

\section{Red blood cells}

Red blood cells (RBC) precipitate intraplaque hemorrhage, which leads to plaque instability. Large extracellular cholesterol crystals in unstable atherosclerotic plaques come from the membrane cholesterol of senescent RBC after intraplaque hemorrhage (Kolodgie et al 2003). Circulating $\mathrm{RBC}$ are able to dampen vessel oxidative damage by means of their antioxidant machinery (glutathione), a physiological role closely related to their ability to uptake, carry and release nitric oxide (NO), thus enhancing local vasodilation and prevention of ischemia (Minetti et al 2007). However, when local inflammatory and oxidative stimulus is strong enough to surpass their capability, RBC behave as "oxidative bullets", extending the oxidative damage by ONOO- transport (Denicola et al 1998). Ischemic and oxidative damage to RBC increases membrane phosphatidylserine (Setty and Betal 2008), become aggregated among them (an event mediated by fibrinogen) and to the surrounding endothelium (mediated by thrombospondin) (Minetti et al 2007). RBC damage and loss of their physiological antioxidant and anti-ischemic role is a frequent complication of unstable hemoglobin conditions, such as sickle cell disease and thallassemia, where there is a vicious circle between RBC dysfunction and ischemia (Raman et al 2006).

Extracorpuscular hemoglobin is able to behave as a powerful proinflammatory and oxidative factor. Extracorpuscular hemoglobin can be inactivated by haptoglobin (Hp). Interestingly, Hp genotype may mediate the extent of this protective response. The $\mathrm{Hb} 1$ allele may exert a protective role in atherosclerosis whereas the $\mathrm{Hb} 2$ allele is associated to increased infarct size in diabetic patients and a poorer response to antioxidant therapy (Levy et al 2007).

\section{Hemostatic factors}

Hemostasis is closely related to macrophage-mediated inflammation, since oxidized LDL is able to increase macrophage apoptosis by the caspase- 3 pathway, wich eventually triggers tissue factor activation and initiation of the extrinsic coagulation cascade (Hutter et al 2004). Thus, the capability of an atheromatous plaque to become clinically significant seems to be closely correlated to its thrombotic capability rather than the mere mechanical disruption. Therefore, current nomenclature highlights the concept highrisk plaque rather than fragile plaque (Fuster et al 2005), since thrombosis is a key issue not only from the high-risk atheromatous plaque but also from the blood of the whole high-risk patient (Corti et al 2003). Type 2 diabetes mellitus increases the inflammatory and pro-coagulant state of the blood when it passes through a Badimon chamber (Osende et al 2001). Hypercholesterolemia, especially when associated with small, dense and oxidized LDL particles, is equally able to increase blood coagulability in vitro (Ananyeva et al 2002) and in vivo (Bai et al 2006). Statins are able to decrease the procoagulant trend in atherosclerotic patients (Kadikoylu et al 2003).

Tissue factor is up-regulated in atherosclerosis (Furnkranz 2005), especially in areas of plaque rupture (Crawley et al 2000). In cell culture experiments, a wide variety of in vitro atherosclerotic putative triggers (CRP, cholesterol esters, glucose, angiotensin) are able to increase the acivity of tissue factor in cultured macrophages and vascular smooth muscle cells (Cirillo et al 2005), an event prevented by in vitro incubation with anti-atherosclerotic drugs, such as statins (Dietzen et al 2007) and antiplatelet drugs (Camera et al 2003). Blood fibrinogen is also closely related to atherosclerosis, since it is triggered by IL-6 (Lowe et al 2004) and correlated to artery occlusion (Nylaende et al 2006).

Platelets are involved in the atherosclerotic process. They form the first hemostatic defense; therefore they initiate and trigger the atheromatous instability (Fuster et al 2005). This fact may explain the benefits of antiplatelet drugs in the secondary prevention of myocardial infarct and unstable angina (ATC 1994). Aspirin inhibits plaque aggregation by irreversible acetylation of Ser530 of COX-1 (Awtry and Loscalzo 2000). Clopidogrel inhibits platelet function by inhibition of ADP receptor. These two antiplatelets can be combined (ATC 2002). However, current evidence-based indications of combined therapy have not been established in the prevention of cardiovascular events (Bhatt et al 2006) and are restricted to the post-stent situation (Bertrand et al 2000) and when a lone drug proves unable to achieve clinical success (Dropinski et al 2007). Related to this, the concept of "aspirin resistance" has emerged in recent years. It may be referred as this lack of clinical antiplatelet control (clinical aspirin resistance), persistence of high platelet activity (in vitro resistance) or persistence of elevated serum or plasma markers of platelet activity (resistance measured as surrogate markers) (Michelson et al 2005). Aspirin resistance (measured as the urinary concentration of thromboxane) has been shown to be an independent cardiovascular risk factor (Eikelboom et al 2002).

Increased platelet activity may trigger endothelial damage (Nomura et al 2001). This vascular pro-inflammatory 
role for the platelets is played by their secretory granules, which secrete chemokines for leukocyte adhesion (Weber 2005), platelet-derived growth factor (PDGF) as a potent growth factor for vascular smooth muscle cells (Lamb et al $2001)$ and TGF- $\beta 1$. TGF- $\beta 1$ is an antiinflammatory cytokine which seems to lose this physiological role in atherosclerosis, where it becomes profibrotic and possibly induces vascular progenitor differentiation towards the smooth muscle lineage (Redondo et al 2007a).

\section{Vascular progenitors}

Although the existence of a unique progenitor for blood and vessel cells (the hemangioblast) has classically been accepted in embryos, the extension of this concept to adult animals took place in 1997 (Asahara et al 1997). Further studies in human beings determined the importance of these progenitors in vascular self-repair. Endothelial progenitor cells (EPCs) are originated in the bone marrow, from CD34+ stem cells (Hristov et al 2003). Enzyme disruption from the stromal cell-derived factor-1 (SDF-1)-rich matrix by matrix metallopeptidase 9 (MMP-9) releases c-kit ligand and allows the exit of these cells from the bone marrow, a process which requires a sufficient blood, vascular and oxygen supply (Hristov and Weber 2004). Early EPCs are positive for several markers, such as CD34+, CD133+, and KDR+. Early EPCs circulate in blood, home to the denuded endothelium, differentiate to endothelial cells (a process where they acquire CD144+ and $\mathrm{vVW}+$ ) and thus repopulate the endothelium or secrete local paracrine factor to increase the physiological state of resident cells (Ingram et al 2005; Bardoff and Dimmeler 2006). The homing of these cells is regulated by several chemokines such as CXCR4 (Hristov et al 2007a).

The first in vitro characterizations of putative EPCs were done by uptake of acetylated low density lipoprotein and Ulex europaeus lectin binding and these capabilities were shown to be shared by monocytes. This evidence led to some research groups to re-consider the property of the term EPC instead of circulating angiogenic cells (Rehman et al 2003). It may be considered that the heterogeneous EPC progeny evolves from the CD34+ stem cell and acquire monocytic (CD14+) and/or endothelial markers (subsequently CD133+, KDR+, CD144+, and vVW+) (Rohde et al 2006). The role of these cells types is double: first is to patch and re-populate the endothelial layer (Op den Buijs 2004; Ingram et al 2005). Second is to behave of tissue stimulators for resident endothelial cells (NakulAquaronne 2003; Rehman et al 2003; Rohde et al 2006).

Clinical studies show a close correlation between the in vitro EPC colony forming units (CFUs) and the in vivo endothelial function (Hill et al 2003). CFU capability, endothelial marker expression and proliferation are dampened when EPCs are incubated with proatherosclerotic triggers (LDL-cholesterol, angiotensin) (Imanishi et al 2005; Pellegatta et al 2006).

Blood levels of EPCs are inversely correlated to Framingham risk factors (Vasa et al 2001b) and to the direct angiographic coronary obstruction (Kunz et al 2006). Low EPC count in patients precedes the coming of atherosclerotic events (Schmidt-Lucke et al 2005) and can be increased by statin treatments (Dimmeler et al 2001; Vasa et al 2001a). However, this putative protective role of EPCs is faced by the fact that their number increases after a heart infarct (Leone et al 2005), although EPC capability to form in vitro CFUs remains diminished in patients with coronary heart disease (Liguori et al 2007) and this post-infarct CFU impairment is associated to post ischemic heart failure (Kissel 2007). Animal models show an increased atherosclerotic growth when cultured EPCs are infused (George et al 2005). Clinical studies also show a decreased EPC after long-term statin treatment (Hristov et al 2007b). Other study shows a direct correlation between angiographic coronary obstruction and EPC number (Güven et al 2006). In addition, a large and recent population-based study shows a direct correlation between Framingham's risk factors and EPC number; a similar correlation is not found in CFU (Xiao et al 2007). This apparent lack of consensus may be explained by the lack of one unified definition of EPC, based on stem ontogeny, transcription factors and markers (Leor and Marber 2006). Another factor to explain this heterogeneity is the dependence on the evolutionary state. In chronic heart failure EPC concentration is increased as a putative defense mechanism against an ischemic insult, although it becomes decreased in more advanced disease states (Valgimigli et al 2004).

Bone marrow can also produce smooth muscle progenitor cells (SPCs), which may possess the capability to increase intima-media thickness and neointimal restenosis (Sata et al 2002), although their role in primary atherosclerosis has been shown to be minimal (Bentzon et al 2007). Atherosclerotic patients have a higher blood concentration of $\mathrm{CD} 14^{+} / \mathrm{CD} 105^{+}$ cells, which give raise to SPC in culture (Sugiyama et al 2006). CD $105^{+}$or endoglin is an accessory receptor of TGF$\beta 1$ which may regulate differentiation towards the smooth muscle lineage (Redondo et al 2007a). CD14+ is monocyte marker which is shared by a wide variety of vascular progenitors (Rehman et al 2003). An unresolved mystery is whether EPCs and SPCs come from a unique progenitor or come from different circulating early progenitors which may use 
different adherence systems (Hoofnagle et al 2004; Ingram et al 2005). Related to this, endothelial to mesenchymal transition has been described in mice embryo. Interestingly, in this model endothelial to mesenchymal progress was enhanced by TGF- $\beta 1$ (Zeisberg et al 2007).

\section{Emerging hematological therapies for cardiovascular disease Progenitor cell therapy}

Pioneer experimental therapeutic attempts on animal models were able to show that in vivo infusion of bone marrow-derived EPCs improved heart and hind limb ischemia. These results suggested that, although a deregulation of EPC function seem to take place in ischemia, artificial self-transplantation may overcome the lack of bone marrow release, blood destruction, lack of adhesion, or abnormal differentiation.

Initial evidence has demonstrated the feasibility and safety of intracoronary infusion of EPCs (Rosenzweig 2006). The majority of clinical evidence to date is obtained in trials where bone marrow-derived mononuclear cells were obtained from the patient and intracoronary infusion was made, in addition to the state-of-the-art interventional therapy. A brief description of several of these trials is shown in Table 2. As a whole, a recent systematic review (Abdel-Latif et al 2007) and a meta-analysis (Hristov et al 2006) conclude that these interventions are feasible, safe, and associated to a small increase in left ventricular ejection fraction (LVEF). In addition, a recent meta-regression using data from ten studies show a dose-response effect for the infused volume when the ejection fraction is measured (Lipinski et al 2007).

Limitations of the current state of the evidence highlight the lack of consensus about the best technical protocol. The vast majority of trials use bone marrow-derive mononuclear

Table 2 Some clinical trials about the potential therapeutical role of EPCs

\begin{tabular}{lll}
\hline Study & Reference & Finding \\
\hline TOPCARE-AMI & $\begin{array}{l}\text { Schächinger et al } \\
2004\end{array}$ & $\begin{array}{l}\text { 8\% increase of LVEF } \\
\text { after 4 months }\end{array}$ \\
REPAIR-AMI & $\begin{array}{l}\text { Schächinger et al } \\
2006\end{array}$ & $\begin{array}{l}2.5 \% \text { increase of LVEF } \\
\text { after 4 months }\end{array}$ \\
BOOST & Meyer et al 2006 & $\begin{array}{l}\text { Similar LVEF after 18 months } \\
\text { ASTAMI }\end{array}$ \\
LOPde et al 2006 & $\begin{array}{l}\text { Similar LVEF after 6 months } \\
(p=0.054) \\
\text { Decreased mortality after } \\
577 \text { days }\end{array}$ \\
\hline
\end{tabular}

Abbreviations: EPCs, endothelial protector cells; LVEF, left ventricular ejection fraction. cells. However, the best volume to extract is unknown. Several studies have used peripheral blood-derived mononuclear cells, although bone marrow material is the leading source in most trials. Nevertheless, bone marrow mononuclear cells include a wide variety of cells beyond EPCs; some of them may differentiate towards a pathogenic direction. As stated by the European Task Force, technical protocols to elucidate the best interventional procedure for progenitorinduced repair are expected to be time and effort-consuming (Bartunek et al 2006). A clinical question to be answered is whether intracoronary infusion of EPCs is able to improve clinical outcomes beyond surrogate markers (such as left ventricular ejection fraction [LVEF]) for a sustained period of time. As far as mechanistic studies are concerned, the issue to be addressed refers to the exact underlying explanation of EPC-mediated benefit. A low amount of intramyocardial bone marrow mononuclear cells is able to adhere in human series using radiolabelling methods, ranging from $9.2 \%$ for bone marrow-derived CD133+ and 6.8\% for bone marrowderived CD133+/CD34+ (Goussetis et al 2006) to 5.5\% for peripheral blood-derived CD34+ at 1 hour after implantation (Blocklet et al 2006). This percentage rises to $6.9 \%-8 \%$ $(2 \mathrm{~h})$ and $2.3 \%-3.2 \%(12 \mathrm{~h})$ after intracoronary infusion of CD133+ cells after G-CSF mobilization and separation from the peripheral blood (Schots et al 2007).

\section{Vascular progenitor modulation by current cardiovascular drugs}

Statins have been shown to increase the number of CD34+/ $\mathrm{KDR}+$ cells in atherosclerotic patients (Vasa et al 2001a). This effect seems to involve the stimulation of PI3K-Akt in the bone marrow, which improves microvessel function and subsequent EPC release (Dimmeler et al 2001). Interestingly, this molecular pathway is uncoupled in the diabetic state (Okon et al 2005) and may be responsible for the decreased concentration of EPCs in diabetic patients (Fadini et al 2006). More recent clinical evidence showed that long-term and long-dose statin treatment was able to decrease of EPCs (measured as CD34+/KDR+) (Hristov et al 2007b). Nevertheless, statin-mediated biphasic effect seems to be associated to a late increase of CD34+/CD144+ EPCs, which show a potential effect of statins on EPC differentiation from early to advanced progenitors (Deschaseaux et al 2007).

Renin-angiotensin system inhibitors have been related to EPC mobilization. In vivo infusion of angiotensin II in rats was able to induce decrease of EPC count and telomerase activity, with a subsequent increase of EPC senescence. These effects were inhibited by administration of the 
AT1-blocker valsartan (Imanishi et al 2005). Irbesartan was also associated to increased EPC counts (Bahlmann 2005). Enalapril was found to increase the bone marrow release of early EPC progenitors in a rat model by involving CD26+ (dipeptidylpeptidase) enzyme stimulation, which induces EPC release (Wang et al 2006a).

Thiazolidinediones (rosiglitazone and pioglitazone) are peroxisome proliferator-activated receptor- $\gamma$ (PPAR- $\gamma$ ) agonists which may possess direct and independent cardiovascular benefits (Erdmann et al 2007), although there is a recent concern for potential danger of rosiglitazonemediated heart failure in high-risk patients (Lipscombe et al 2007). Incubation with rosiglitazone induces in vitro endothelial differentiation from a cluster of vascular progenitors (Wang et al 2004). Pioglitazone has been found to restore the quantitative and qualitative defect (measured as impaired in vitro formation of capillaries) which is found in type 2 diabetes patients (Wang et al 2006b). This effect may be mediated by a PPAR- $\gamma$-dependent increase of EPC adhesion under flow (Redondo et al 2007b). This may explain the increased EPC counts in diabetic (Wang et al 2006b) and nondiabetic patients (Werner et al 2007) under pioglitazone treatment.

Some antiatherosclerotic drugs have been shown to decrease the proliferation of EPC after in vitro incubation. Aspirin has been shown to possess this capability at milimolar concentrations (Chen et al 2006). This capability is also shared by COX-2 inhibitors (Colleselli et al 2006). Rapamycin is a potent in vitro inhibitor of EPC growth (Imanishi et al 2006), which may mediate the endothelial damage of rapamycin-coated stents (Zhao et al 2008). Future research will clear the role of differential progeny, isolation, adhesion and differentiation in these cell culture experiments.

Eventually, the physical activity has been proven to affect EPC number and function. Physical training in mice increased the number of circulating EPCs (Laufs et al 2004) being these results reproduced in patients (Steiner et al 2005). This is related to increased blood levels of VEGF and SDF induced by exercise (Sarto et al 2007). Some results were able to correlate exercise-mediated EPC increase with increased levels of EPO in trained subjects (Steiner et al 2005). Cardiac rehabilitation was equally able to increase EPC CFUs and decrease EPC apoptosis (Paul et al 2007).

\section{Vascular progenitor modulation by target-designed novel molecules}

Being EPC derived from the hematological stem cells committed towards the myeloid lineage, one of the most intuitive interventions to induce EPC release is granulocyte-colony stimulating factor (G-CSF), a stimulus for myeloid recovery (Ossenkoppele et al 2004). Studies on animal models were able to show a G-CSF-mediated increase of circulating CD34+ cells, which was associated to improved angiogenesis and conserved myocardial function (Ott et al 2005). Treatment with G-CSF treatment was able to increase the blood levels of CD34+ cells in coronary disease patients (Suarez de Lezo et al 2005) with a related improvement in LVEF (Nienaber et al 2006), G-CSF treatment is able to increase CFU capability, although in vitro migration remained diminished (Honold et al 2006). The randomized REVIVAL-2 trial was unable to find a significant change on infarct size, LVEF, or coronary obstruction (Zohlnhöfer et al 2006). The STEMMI trial was equally unable to find a significant benefit for G-CSF treatment (Ripa et al 2006). Advanced age may dampen the efficacy of G-CSF to increase EPC number and/or function (Lehrke et al 2006).

Another approach is the usage of G-CSF to enrich EPC extraction by apheresis, as a purified source of EPCs for therapeutical intracoronary infusion (Ripa et al 2007). However, in addition to the well-known side effects of G-CSF (such as bone pain and influenza-like syndrome), the inflammatory state of atherosclerotic lesions might be increased due to the unspecific release of leukocytes from the bone marrow, with an initial strengthened release of monocytes (Parissis et al 2006).

Another approach to increase EPC release from the bone marrow is AMD3100, a small molecule which antagonizes the binding of SDF and CXCR4. Animal experimental evidence shows a significant increase of CD34+ (Burroughs et al 2005), being these results reproduced in human volunteers (Liles et al 2005; Flomenberg et al 2005). Nevertheless, caution should be addressed for the implementation of his compound, since it may also inhibit EPC homing from the blood to the denuded vessel (Yin et al 2007) and increase unspecific leukocyte release, which may increase plaque fragility (Zernecke et al 2008).

Another substance to increase EPC number and function is erythropoietin (EPO). In animal experimental ischemia, EPO has been found to possess infarct-limiting effect (Moon et al 2003) and thus maintain LVEF (Scheneider et al 2007). In addition to the direct protective effect for myocytes (Hanlon et al 2005), EPO is able to increase EPC blood concentration in mice models of ischemia (Urao et al 2006). A single bolus of EPO has been shown to increase blood number of EPCs (CD34+/CD45-) in patients with acute 
myocardial infarction, although LVEF remains the same after four months (Lipsic et al 2006).

Current efforts are being made in order to obtain compounds which affect EPC release, adhesion and differentiation in a selective manner. According to this approach, a cGRD (cyclic Arg-Gly-Asp) peptide-coated stent was found to selectively induce EPC adhesion in porcine coronary arteries and inhibit neointimal hyperplasia (Blindt et al 2006).

\section{Vascular implications in hematological malignancies}

Experimental (Fischer et al 2007) and clinical (Cohen et al 2007) evidence showed the therapeutical value of antiangiogenic cancer treatment. In hematological malignancies, multiple myeloma is the paradigm of neoplasic disease where antiangiogenic therapy has been established in the state-of-the-art clinical practice, with thalidomide (Facon et al 2007) and lenalidomide (Dimopoulos et al 2007). Increased EPC numbers are correlated to the clinical outcome in multiple myeloma, being decreased after thalidomide treatment (Zhang et al 2005). Moreover, a significant population of myeloma patients possesses circulating EPCs which come from the neoplasic clone (Rigolin et al 2006).

These results about the clonal (neoplasic) origin of a substantial population of tumor growth-related endothelial cells has equally been found in chronic myelogenous leukemia, where bcr-abl protein was found in endothelial cells generated in vitro from the bone marrow of six patients (Gunsilius et al 2000). Further evidence was able to identify a bone marrow chronic myelogenous leukemia progenitor with hemangioblast capability (Fang et al 2005). Imatinib (bcr-abl blocker) may possess some degree of angiogenic-related mechanism of action, since it has been shown to decrease cell secretion of VEGF in cell culture studies (Ebos et al 2002).

\section{Conclusion and clinical perspective}

Despite the increase in our knowledge of atherosclerosis, cardiovascular mortality remains as the first cause of death. Research on the role of blood and marrow in atherosclerosis may lead to the implementation of novel, independent and specific risk factors for the early diagnose and treatment monitoring. Moreover, current discoveries on the regulation of vascularization and ischemia are expected to generate a rational therapeutical approach to control hematological malignancies.

\section{Disclosure}

The authors report no conflicts of interest in this work.

\section{References}

Abdel-Latif A, Bolli R, Tleyjeh IM, et al. 2007. Adult bone marrow-derived cells for cardiac repair: a systematic review and meta-analysis. Arch Intern Med, 167:989-7.

Ananyeva NM, Kouiavskaia DV, Shima M, et al. 2002. Intrinsic pathway of blood coagulation contributes to thrombogenicity of atherosclerotic plaque. Blood, 99:4475-5.

[ATC] Antiplatelets Trialists' Collaboration. 1994. Collaborative overview of randomised trials of antiplatelet therapy-I: Prevention of death, myocardial infarction, and stroke by prolonged antiplatelet therapy in various categories of patients. Antiplatelet Trialists' Collaboration. BMJ, 308:81-6.

[ATC] Antithrombotic Trialists' Collaboration. 2002. Collaborative meta-analysis of randomised trials of antiplatelet therapy for prevention of death, myocardial infarction, and stroke in high risk patients. $B M J, 324: 71-6$.

Asahara T, Murohara T, Sullivan A, et al. 1997. Isolation of putative progenitor endothelial cells for angiogenesis. Science, 275:964-7.

Assmus B, Fischer-Rasokat U, Honold J, et al. 2007. Transcoronary transplantation of functionally competent BMCs is associated with a decrease in natriuretic peptide serum levels and improved survival of patients with chronic postinfarction heart failure: results of the TOPCARE-CHD Registry. Circ Res, 100:1234-1.

Avanzas S, Quiles J, Lopez de Sa, et al. 2004. Neutrophil count and infarct size in patients with acute myocardial infarction. Int J Cardiol, 97:155-6.

Awtry EH, Loscalzo J. 2000. Aspirin. Circulation, 101:1206-8.

Bai H, Liu BW, Deng ZY, et al. 2006. Plasma very-low-density lipoprotein, low-density lipoprotein, and high-density lipoprotein oxidative modification induces procoagulant profiles in endogenous hypertriglyceridemia. Free Radic Biol Med, 40:1796-3.

Bansal S, Ridker PM. 2007. Comparison of characteristics of future myocardial infarctions in women with baseline high versus baseline low levels of high-sensitivity C-reactive protein. Am J Cardiol, 99:1500-3.

Bardoff C, Dimmeler S. 2006. Neovascularization and cardiac repair by bone marrow-derived stem cells. Handb Exp Pharmacol, 174:283-8.

Bartunek J, Dimmeler S, Drexler H, et al. 2006. The consensus of the task force of the European Society of Cardiology concerning the clinical investigation of the use of autologous adult stem cells for repair of the heart. Eur Heart J, 27:1338-0.

Bentzon JF, Sondergaard CS, Kassem M, et al. 2007. Smooth muscle cells healing atherosclerotic plaque disruptions are of local, not blood, origin in apolipoprotein E knockout mice. Circulation, 116:2053-1.

Bertrand ME, Rupprecht HJ, Urban P, et al. 2000. Double-blind study of the safety of clopidogrel with and without a loading dose in combination with aspirin compared with ticlopidine in combination with aspirin after coronary stenting : the clopidogrel aspirin stent international cooperative study (CLASSICS). Circulation, 102:624-9.

Bhatt DL, Fox KA, Hacke W, et al. 2006. Clopidogrel and aspirin versus aspirin alone for the prevention of atherothrombotic events. $N$ Engl J Med, 354:1706-7.

Bahlmann FH, de Groot K, Mueller O, et al. 2005. Stimulation of endothelial progenitor cells: a new putative therapeutic effect of angiotensin II receptor antagonists. Hypertension, 45:526-9.

Binder CJ, Hörkkö S, Dewan A, et al. 2003. Pneumococcal vaccination decreases atherosclerotic lesion formation: molecular mimicry between Streptococcus pneumoniae and oxidized LDL. Nat. Med, 9:736-3

Blake GJ, Rifai N, Buring JE, et al. 2003. Blood pressure, C-reactive protein, and risk of future cardiovascular events. Circulation, 108:2993-9. 
Blindt R, Vogt F, Astafieva I, et al. 2006. A novel drug-eluting stent coated with an integrin-binding cyclic Arg-Gly-Asp peptide inhibits neointimal hyperplasia by recruiting endothelial progenitor cells. $J \mathrm{Am}$ Coll Cardiol, 47:1786-5.

Blocklet D, Toungouz M, Berkenboom G, et al. 2006. Myocardial homing of nonmobilized peripheral-blood CD34+ cells after intracoronary injection. Stem Cells, 24:333-6.

Burroughs L, Mielcarek M, Little MT, et al. 2005. Durable engraftment of AMD3100-mobilized autologous and allogeneic peripheral-blood mononuclear cells in a canine transplantation model. Blood, 106:4002-8.

Camera M, Frigerio M, Toschi V, et al. 2003. Platelet activation induces cell-surface immunoreactive tissue factor expression, which is modulated differently by antiplatelet drugs. Arterioscler Thromb Vasc Biol, 23:1690-6.

Chapman CM, Beilby JP, McQuillan BM, et al. 2004. Monocyte count, but not C-reactive protein or interleukin-6, is an independent risk marker for subclinical carotid atherosclerosis. Stroke, 35:1619-4.

Chen TG, Chen JZ, Xie XD. 2006. Effects of aspirin on number, activity and inducible nitric oxide synthase of endothelial progenitor cells from peripheral blood. Acta Pharmacol Sin, 27:430-6.

Cirillo P, Molino P, Calabro P, et al. 2005. C-reactive protein induces tissue factor expression and promotes smooth muscle and endothelial cell proliferation. Cardiovasc Res, 68:47-5.

Cohen MH, Gootenberg J, Keegan P, et al. 2007. FDA drug approval summary: bevacizumab (Avastin) plus Carboplatin and Paclitaxel as first-line treatment of advanced/metastatic recurrent nonsquamous non-small cell lung cancer. Oncologist, 12:713-18.

Colleselli D, Bijuklic K, Mosheimer BA, et al. 2006. Inhibition of cyclooxygenase (COX)-2 affects endothelial progenitor cell proliferation. Exp Cell Res, 312:2933-1.

Corti R, Fuster V, Badimon JJ. 2003. Pathogenetic concepts of acute coronary syndromes. $J$ Am Coll Cardiol, 41:7S-14S.

Crawley J, Lupu F, Westmukett AD, et al. 2000. Expression, localization, and activity of tissue factor pathway inhibitor in normal and atherosclerotic human vessels. Arterioscler Thromb Vasc Biol, 20:1362-3.

Denicola A, Souza JM, Radi R. 1998. Diffusion of peroxynitrite across erythrocyte membranes. Proc Natl Acad Sci USA, 95:3566-1.

Deschaseaux F, Selmani Z, Falcoz PE, et al. 2007. Two types of circulating endothelial progenitor cells in patients receiving long term therapy by HMG-CoA reductase inhibitors. Eur J Pharmacol, 562:111-8.

Dietzen DJ, Page KL, Tetzloff TA, et al. 2007. Inhibition of 3-hydroxy3-methylglutaryl coenzyme A (HMG CoA) reductase blunts factor $\mathrm{VIIa} /$ tissue factor and prothrombinase activities via effects on membrane phosphatidylserine. Arterioscler Thromb Vasc Biol, 27:690-6.

Dimmeler S, Aicher A, Vasa M, et al. 2001. HMG-CoA reductase inhibitors (statins) increase endothelial progenitor cells via the PI 3-kinase/Akt pathway. J Clin Invest, 108:391-7.

Dimopoulos M, Spencer A, Attal M, et al. 2007. Lenalidomide plus dexamethasone for relapsed or refractory multiple myeloma. $N$ Engl J Med, 357:2123-2.

Dropinski J, Jakiela B, Sanak M, et al. 2007. The additive antiplatelet action of clopidogrel in patients with coronary artery disease treated with aspirin. Thromb Haemost, 98:201-9.

Ebos JM, Tran J, Master Z, et al. 2002. Imatinib mesylate (STI-571) reduces Bcr-Abl-mediated vascular endothelial growth factor secretion in chronic myelogenous leukemia. Mol Cancer Res. 1:89-5.

Eikelboom JW, Hirsch J, Weitz JI, et al. 2002. Aspirin-resistant thromboxane biosynthesis and the risk of myocardial infarction, stroke, or cardiovascular death in patients at high risk for cardiovascular events. Circulation, 105:1650-5.

Erdmann E, Dormandy JA, Charbonnel B, et al. 2007. The effect of pioglitazone on recurrent myocardial infarction in 2,445 patients with type 2 diabetes and previous myocardial infarction: results from the PROactive (PROactive 05) Study. J Am Coll Cardiol, 49:1772-0.
Ezzati M, Vander Hoorn S, Lawes CM, et al. 2005. Rethinking the "diseases of affluence" paradigm: global patterns of nutritional risks in relation to economic development. PLoS Med, 2(5):e133.

Fingerle-Rowson G, Auers J, Kreuzer E, et al. 1998. Expansion of CD14+CD16+ monocytes in critically ill cardiac surgery patients. Inflammation, 22:367-9.

Fortmann SP, Ford E, Criqui MH, et al. 2004. CDC/AHA Workshop on Markers of Inflammation and Cardiovascular Disease: Application to Clinical and Public Health Practice: report from the population science discussion group. Circulation, 110:e554-9.

Facon T, Mary JY, Hulin C, et al. 2007. Melphalan and prednisone plus thalidomide versus melphalan and prednisone alone or reducedintensity autologous stem cell transplantation in elderly patients with multiple myeloma (IFM 99-06): a randomised trial. Lancet, 370:1209-8.

Fadini GP, Sartore S, Albiero M, et al. 2006. Number and function of endothelial progenitor cells as a marker of severity for diabetic vasculopathy. Arterioscler Thromb Vasc Biol, 26:2140-6.

Fang B, Zheng C, Liao L, et al. 2005. Identification of human chronic myelogenous leukemia progenitor cells with hemangioblastic characteristics. Blood, 105:2733-40.

Fischer C, Jonckx B, Mazzone M, et al. 2007. Anti-PlGF inhibits growth of VEGF(R)-inhibitor-resistant tumors without affecting healthy vessels. Cell, 131:463-5.

Flomenberg N, Devine SM, Dipersio JF, et al. 2005. The use of AMD3100 plus G-CSF for autologous hematopoietic progenitor cell mobilization is superior to G-CSF alone. Blood, 106:1867-4.

Furnkranz A, Schober A, Bochkov VN, et al. 2005. Oxidized phospholipids trigger atherogenic inflammation in murine arteries. Arterioscler Thromb Vasc Biol, 25:633-8.

Fuster V, Moreno PR; Fayad ZA, et al. 2005. Atherothrombosis and highrisk plaque: part I: evolving concepts. $J$ Am Coll Cardiol, 46:937-4.

George J, Afek A, Abashidze A, et al. 2005. Transfer of endothelial progenitor and bone marrow cells influences atherosclerotic plaque size and composition in apolipoprotein E knockout mice. Arterioscler Thromb Vasc Biol, 25:2636-1.

Goussetis E, Manginas A, Koutelou M, et al. 2006. Intracoronary infusion of $\mathrm{CD} 133+$ and $\mathrm{CD} 133-\mathrm{CD} 34+$ selected autologous bone marrow progenitor cells in patients with chronic ischemic cardiomyopathy: cell isolation, adherence to the infarcted area, and body distribution. Stem Cells, 24:2279-3.

Grainger DJ, Kemp PR, Metcalfe JC, et al. 1995. The serum concentration of active transforming growth factor-beta is severely depressed in advanced atherosclerosis. Nat Med, 1:74-9.

Gunsilius E, Duba HC, Petzer AL, et al. 2000. Evidence from a leukaemia model for maintenance of vascular endothelium by bone-marrowderived endothelial cells. Lancet, 355:1688-1.

Güven H, Shepherd RM, Bach RG, et al. 2006. The number of endothelial progenitor cell colonies in the blood is increased in patients with angiographically significant coronary artery disease. $\mathrm{J} \mathrm{Am} \mathrm{Coll} \mathrm{Cardiol}$, 48:1579-7.

Haim M, Boyko V, Goldbourt U, et al. 2004. Predictive value of elevated white blood cell count in patients with preexisting coronary heart disease: the Bezafibrate Infarction Prevention Study. Arch Intern Med. 164:433-9.

Hanlon PR, Fu P, Wright GL, et al. 2005. Mechanisms of erythropoietinmediated cardioprotection during ischemia-reperfusion injury: role of protein kinase $\mathrm{C}$ and phosphatidylinositol 3-kinase signaling. FASEB J, 19:1323-5.

Hartas D, Yacov N, Gilburd B, et al. 2002. Oral tolerance with heat shock protein 65 attenuates Mycobacterium tuberculosis-induced and high-fat-diet-driven atherosclerotic lesions. J Am Coll Cardiol, 40:1333-8.

Hansson GK, Libby P. 2006. The immune response in atherosclerosis: a double-edged sword. Nat Rev Immunol, 6:508-19.

Hansson GK, Robertson AK. 2006. TGF-beta in atherosclerosis. Arterioscler Thromb Vasc Biol, 24:E137. 
Helft G, Worthley SG, Fuster V, et al. 2002. Progression and regression of atherosclerotic lesions: monitoring with serial noninvasive magnetic resonance imaging. Circulation, 105:993-8.

Hill JM, Zalos G, Halcox JP, et al. 2003. Circulating endothelial progenitor cells, vascular function, and cardiovascular risk. $N$ Engl $J$ Med, 348:593-0.

Honold J, Lehmann R, Heeschen C, et al. 2006. Effects of granulocyte colony simulating factor on functional activities of endothelial progenitor cells in patients with chronic ischemic heart disease. Arterioscler Thromb Vasc Biol, 26:2238-3.

Hoofnagle MH, Wamhoff BR, Owens GK. 2004. Lost in transdifferentiation. $J$ Clin Invest, 113:1249-1.

Hoogeveen RC, Morrison A, Boerwinkle E, et al. 2005. Plasma MCP-1 level and risk for peripheral arterial disease and incident coronary hear disease: Atherosclerosis Risk in Communities study. Atherosclerosis, 83:301-7.

Hristov M, Erl W, Weber PC. 2003. Endothelial progenitor cells: mobilization, differentiation, and homing. Arterioscler Thromb Vasc Biol, 23:1185-9

Hristov M, Weber C. 2004. Endothelial progenitor cells: characterization, pathophysiology, and possible clinical relevance. $J$ Cell Mol Med, 8:498-8.

Hristov M, Heussen N, Schober A, et al. 2006. Intracoronary infusion of autologous bone marrow cells and left ventricular function after acute myocardial infarction: a meta-analysis. J Cell Mol Med, 10:727-3.

Hristov M, Zernecke A, Bidzhekov K, et al. 2007. Importance of CXC chemokine receptor 2 in the homing of human peripheral blood endothelial progenitor cells to sites of arterial injury. Circ Res, 100:590-7.

Hristov M, Fach C, Becker C, et al. 2007. Reduced numbers of circulating endothelial progenitor cells in patients with coronary artery disease associated with long-term statin treatment. Atherosclerosis, 192:413-0

Hutter R, Valdiviezo C, Sauter BV, et al. 2004. Caspase-3 and tissue factor expression in lipid-rich plaque macrophages: evidence for apoptosis as link between inflammation and atherothrombosis. Circulation, 109:2001-8.

Ikonomidis I, Andreotti F, Economou E, et al. 1999. Increased proinflammatory cytokines in patients with chronic stable angina and their reduction by aspirin. Circulation, 100:793-8.

Imanishi T, Hano T, Nishio I. 2005. Angiotensin II accelerates endothelial progenitor cell senescence through induction of oxidative stress. J Hypertens, 23:97-4.

Imanishi T, Kobayashi K, Kuki S, et al. 2006. Sirolimus accelerates senescence of endothelial progenitor cells through telomerase inactivation. Atherosclerosis, 189:288-6.

Ingram DA, Caplice NM, Yoder MC. 2005. Unresolved questions, changing definitions, and novel paradigms for defining endothelial progenitor cells. Blood, 106:1525-1.

Johnsen SH, Fosse E, Joakimsen O, et al. 2005. Monocyte count is a predictor of novel plaque formation: a 7-year follow-up study of 2610 persons without carotid plaque at baseline the Tromsø Study. Stroke, 36:715-9.

Kadikoylu G, Yukselen V, Yavasoglu I, et al. 2003. Hemostatic effects of atorvastatin versus simvastatin. Ann Pharmacother, 37:478-4.

Khreiss T, József L, Potempa LA, et al. 2004. Conformational rearrangement in C-reactive protein is required for proinflammatory actions on human endothelial cells. Circulation, 109:2016-22.

Kissel CK, Lehmann R, Assmus B, et al. 2007. Selective functional exhaustion of hematopoietic progenitor cells in the bone marrow of patients with postinfarction heart failure. $\mathrm{J} \mathrm{Am} \mathrm{Coll} \mathrm{Cardiol,}$ 49:2341-9.

Kolodgie FD, Gold HK, Burke AP, et al. 2003. Intraplaque hemorrhage and progression of coronary atheroma. $N$ Engl J Med, 349:2316-5.

Kuchibhotla S, Vanegas D, Kennedy DJ, et al. 2008. Absence of CD36 protects against atherosclerosis in ApoE knock-out mice with no additional protection provided by absence of scavenger receptor $\mathrm{AI} / \mathrm{II}$ Cardiovasc Res, 78:185-96.
Kunz GA, Liang G, Cuculi F, et al. 2006. Circulating endothelial progenitor cells predict coronary artery disease severity. Am Heart $J$, 152:190-5.

Lamb DJ, Avades TY, Ferns GA. 2001. Endogenous neutralizing antibodies against platelet-derived growth factor-AA inhibit atherogenesis in the cholesterol-fed rabbit. Arterioscler Thromb Vasc Biol, 21:997-3.

Langenberg C, Bergstrom J, Scheidt-Nave C, et al. 2006. Cardiovascular death and the metabolic syndrome: role of adiposity-signaling hormones and inflammatory markers. Diabetes Care, 29:1363-9.

Laufs U, Werner N, Link A, et al. 2004. Physical training increases endothelial progenitor cells, inhibits neointima formation, and enhances angiogenesis. Circulation, 109:220-6.

Laviades C, Varo N, Diez J. 2000. Transforming growth factor beta in hypertensives with cardiorenal damage. Hypertension, 36:517-22.

Lehrke S, Mazhari R, Durand DJ, et al. 2006. Aging impairs the beneficial effect of granulocyte colony-stimulating factor and stem cell factor on post-myocardial infarction remodeling. Circ Res, 99:553-0.

Leone AM, Rutella S, Bonanno G, et al. 2005. Mobilization of bone marrowderived stem cells after myocardial infarction and left ventricular function. Eur Heart J, 26:1196-4.

Leor J and Marber M. 2006. Endothelial progenitors: a new Tower of Babel? J Am Coll Cardiol, 48:1588-0.

Levy AP, Levy JE, Kalet-Litman S, et al. 2007. Haptoglobin genotype is a determinant of iron, lipid peroxidation and macrophage accumulation in the atherosclerotic plaque. Arterioscl Thomb Vasc Biol, 27:134-40.

Liles WC, Rodger E, Broxmeyer HE, et al. 2005. Augmented mobilization and collection of $\mathrm{CD} 34+$ hematopoietic cells from normal human volunteers stimulated with granulocyte-colony-stimulating factor by single-dose administration of AMD3100, a CXCR4 antagonist Transfusion, 45:295-0.

Lipinski MJ, Biondi-Zoccai GG, Abbate A, et al. 2007. Impact of intracoronary cell therapy on left ventricular function in the setting of acute myocardial infarction: a collaborative systematic review and meta-analysis of controlled clinical trials. J Am Coll Cardiol, 50:1761-7.

Lipscombe LL, Gomes T, Lévesque LE, et al. 2007. Thiazolidinediones and cardiovascular outcomes in older patients with diabetes. JAMA, 298:2634-3.

Lipsic E, van der Meer P, Voors AA, et al. 2006. A single bolus of a longacting erythropoietin analogue darbepoetin alfa in patients with acute myocardial infarction: a randomized feasibility and safety study. Cardiovasc Drugs Ther, 20:135-1.

Lloyd-Jones DM, Liu K, Tian L, et al. 2006. Narrative review: Assessment of C-reactive protein in risk prediction for cardiovascular disease. Ann Intern Med, 145:35-42.

Lowe GD, Rumley A, McMahon AD, et al. 2004. Interleukin-6, fibrin D-dimer, and coagulation factors VII and XIIa in prediction of coronary heart disease. Arterioscler Thromb Vasc Biol, 24:1529-4.

Lunde K, Solheim S, Aakhus S, et al. 2006. Intracoronary injection of mononuclear bone marrow cells in acute myocardial infarction. $N$ Engl J Med, 355:1199-9.

Maekawa Y, Anzai T, Yoshikawa T, et al. 2002. Prognostic significance of peripheral monocytosis after reperfused acute myocardial infarction:a possible role for left ventricular remodeling. J Am Coll Cardiol, 39:241-6.

Madjid M, Awan I, Willerson JT, et al. 2004. Leukocyte count and coronary heart disease: implications for risk assessment. J Am Coll Cardiol, 44:1945-6.

Martin-Fuentes P, Civeira F, Recalde E, et al. 2007. Individual variation of scavenger receptor expression in human macrophages with oxidized low-density lipoprotein is associated with a differential inflammatory response. J Immunol, 179:3242-8.

Meisel SR, Pauzner H, Shechter M, et al. 1998. Peripheral monocytosis following acute myocardial infarction: incidence and its possible role as a bedside marker of the extent of cardiac injury. Cardiology, 90:52-7.

Meyer GP, Wollert KC, Lotz J, et al. 2006. Intracoronary bone marrow cell transfer after myocardial infarction: eighteen months' follow-up data from the randomized, controlled BOOST (BOne marrOw transfer to enhance ST-elevation infarct regeneration) trial. Circulation, 113:1287-4. 
Minetti M, Agati L, Malorni W, et al. 2007. The microenvironment can shift erythrocytes from a friendly to a harmful behavior: pathogenetic implications for vascular diseases. Cardiovasc Res, 75:2-8.

Moon C, Krawczyk M, Ahn D, et al. 2003. Erythropoietin reduces myocardial infarction and left ventricular functional decline after coronary artery ligation in rats. Proc Natl Acad Sci USA, 100:11612-7.

Nakul-Aquaronne D, Bayle J, Frelin C. 2003. Coexpression of endothelial markers and $\mathrm{CD} 14$ by cytokine mobilized CD34+ cells under angiogenic stimulation. Cardiovasc Res, 57:816-3.

Naya M, Tsukamoto T, Morita K, et al. 2007. Plasma interleukin-6 and tumor necrosis factor-alpha can predict coronary endothelial dysfunction in hypertensive patients. Hypertens Res, 30:541-8.

Nienaber CA, Petzsch M, Kleine HD, et al. 2006. Effects of granulocyte-colony-stimulating factor on mobilization of bone-marrow-derived stem cells after myocardial infarction in humans. Nat Clin Pract Cardiovasc Med, 3(Suppl1):S73-7.

Nomura S, Tandon NN, Nakamura T, et al. 2001. High-shear-stress-induced activation of platelets and microparticles enhances expression of cell adhesion molecules in THP-1 and endothelial cells. Atherosclerosis, 158:277-7.

Nuñez J, Facila L, Llacer A, et al. 2005. Prognostic value of white blood cell count in acute myocardial infarction: long-term mortality. Rev Esp Cardiol, 58:631-9.

Nylaende M, Kroese AJ, Morken B, et al. 2007. Beneficial effects of 1-year optimal medical treatment with and without additional PTA on inflammatory markers of atherosclerosis in patients with PAD. Results from the Oslo Balloon Angioplasty versus Conservative Treatment (OBACT) study. Vasc Med, 12:275-3.

Okon EB, Chung AW, Rauniyar P, et al. 2005. Compromised arterial function in human type 2 diabetic patients. Diabetes, 54:2415-3.

Op den Buijs J, Musters M, Verrips T, et al. 2004. Mathematical modeling of vascular endothelial layer maintenance: the role of endothelial cell division, progenitor cell homing, and telomere shortening. Am J Physiol Heart Circ Physiol, 287:H2651-8.

Osende JI, Badimon JJ, Fuster V, et al. 2001. Blood thrombogenicity in type 2 diabetes mellitus patients is associated with glycemic control. $J \mathrm{Am}$ Coll Cardiol, 38:1307-2.

Ossenkoppele GJ, Graveland WJ, Sonneveld P, et al. 2004. The value of fludarabine in addition to ARA-C and G-CSF in the treatment of patients with high-risk myelodysplastic syndromes and AML in elderly patients. Blood, 103:2908-3.

Ott I, Keller U, Knoedler M, et al. 2005. Endothelial-like cells expanded from CD34+ blood cells improve left ventricular function after experimental myocardial infarction. FASEB J, 19:992-4.

Parissis J, Filippatos G Adamopoulos S, et al. 2006. Hematopoietic colony stimulating factors in cardiovascular and pulmonary remodeling: promoters or inhibitors? Curr Pharm Des, 12:2689-9.

Paul JD, Powell TM, Thompson M, et al. 2007. Endothelial progenitor cell mobilization and increased intravascular nitric oxide in patients undergoing cardiac rehabilitation. J Cardiopulm Rehabil Prev, $27: 65-3$.

Pellegatta F, Bragheri M, Grigore L, et al. 2006. In vitro isolation of circulating endothelial progenitor cells is related to the high density lipoprotein plasma levels. Int J Mol Med, 17:203-8.

Raman SV, Simonetti OP, Cataland SR, et al. 2006. Myocardial ischemia and right ventricular dysfunction in adult patients with sickle cell disease. Haematologica, 91:1329-5.

Redondo S, Santos-Gallego CG, Tejerina T. 2007. TGF-beta1: a novel target for cardiovascular pharmacology. Cytokine Growth Factor Rev, 18:279-6.

Redondo S, Hristov M Gumber D, et al. 2007. Biphasic effect of pioglitazone on isolated human endothelial progenitor cells: involvement of peroxisome proliferator-activated receptor-gamma and transforming growth factor-beta1. Thromb Haemost, 97:979-7.

Rehman J, Li J, Orschell CM, et al. 2003. Peripheral blood "endothelial progenitor cells" are derived from monocyte/macrophages and secrete angiogenic growth factors. Circulation, 107:1164-9.
Ridker PM, Buring JE, Cook NR, et al. 2003. C-reactive protein, the metabolic syndrome, and risk of incident cardiovascular events: an 8-year follow-up of 14719 initially healthy American women. Circulation, 107:391-7.

Rigolin GM, Fraulini C, Ciccone M, et al. 2006. Neoplastic circulating endothelial cells in multiple myeloma with $13 \mathrm{q} 14$ deletion. Blood, 107:2531-5.

Ripa RS, Jorgensen E, Wamg Y, et al. 2006. Stem cell mobilization induced by subcutaneous granulocyte-colony stimulating factor to improve cardiac regeneration after acute ST-elevation myocardial infarction: result of the double-blind, randomized, placebo-controlled stem cells in myocardial infarction (STEMMI) trial. Circulation, 113:1983-2.

Rohde E, Malischnik C, Thaler D, et al. 2006. Blood monocytes mimic endothelial progenitor cells. Stem Cells, 24:357-7.

Rosenzweig A. 2006. Cardiac cell therapy—mixed results from mixed cells. N Engl J Med, 355:1274-7.

Ross R. 1999. Atherosclerosis - an inflammatory disease. N Engl J Med, $340: 115-26$

Rothenbacher D, Brenner H, Mertens T, et al. 2005. Prognostic value of interleukin-1 receptor antagonist gene polymorphism and cytomegalovirus seroprevalence in patients with coronary artery disease. BMC Cardiovasc Visor, 5:10.

Sarto P, Balducci E, Balconi G, et al. 2007. Effects of exercise training on endothelial progenitor cells in patients with chronic heart failure. J Card Fail, 13:701-8.

Sata M, Saiura A, Kunisato A, et al. 2002. Hematopoietic stem cells differentiate into vascular cells that participate in the pathogenesis of atherosclerosis. Nat Med, 8:403-9.

Schächinger V, Assmuss B, Britten MB, et al. 2004. Transplantation of progenitor cells and regeneration enhancement in acute myocardial infarction: final one-year results of the TOPCARE-AMI Trial. $J$ Am Coll Cardiol, 44:1690-9.

Schächinger V, Erbs S, Elsässer A, et al. 2006. Improved clinical outcome after intracoronary administration of bone-marrow-derived progenitor cells in acute myocardial infarction: final 1-year results of the REPAIR-AMI trial. Eur Heart J, 27:2775-3.

Schmidt-Lucke C, Rössig L, Fichtlscherer S, et al. 2005. Reduced number of circulating endothelial progenitor cells predicts future cardiovascular events: proof of concept for the clinical importance of endogenous vascular repair. Circulation, 111:2981-7.

Schneider C, Jaquet K, Malisius R, et al. 2007. Attenuation of cardiac remodelling by endocardial injection of erythropoietin: ultrasonic strain-rate imaging in a model of hibernating myocardium. Eur Heart $J$, 28:499-9.

Sen S, Hinderliter A, Sen PK, et al. 2007. Association of leukocyte count with progression of aortic atheroma in stroke/transient ischemic attack patients. Stroke, 38:2900-5.

Setty BN, Betal SG. 2008. Microvascular endothelial cells express a phosphatidylserine receptor: a functionally active receptor for phosphatidylserine-positive erythrocytes. Blood, 111:905-14.

Schots R, De Keulenaer G, Schoors D, et al. 2007. Evidence that intracoronary-injected CD133+ peripheral blood progenitor cells home to the myocardium in chronic postinfarction heart failure. Exp Hematol, 35:1884-0.

Shoenfeld Y, Gerli R, Doria A, et al. 2005. Accelerated atherosclerosis in autoimmune rheumatic diseases. Circulation, 112:3337-7.

Steiner S, Niessner A, Ziegler S, et al. 2005. Endurance training increases the number of endothelial progenitor cells in patients with cardiovascular risk and coronary artery disease. Atherosclerosis, 181:305-0.

Suárez de Lezo J, Torres A, Herrera I, et al. 2005. Effects of stem-cell mobilization with recombinant human granulocyte colony stimulating factor in patients with percutaneously revascularized acute anterior myocardial infarction. Rev Esp Cardiol, 58:253-1.

Sugiyama S, Kugiyama K, Nakamura S, et al. 2006. Characterization of smooth muscle-like cells in circulating human peripheral blood. Atherosclerosis, 87:351-2. 
Szodoray P, Timar O, Veres K, et al. 2006. TH1/TH2 imbalance, measured by circulating and intracytoplasmic inflammatory cytokines immunological alterations in acute coronary syndrome and stable coronary artery disease. Scand J Immunol, 64:336-4.

Thakore AH, Guo CY, Larson MG, et al. 2007. Association of multiple inflammatory markers with carotid intimal medial thickness and stenosis (from the Framingham Heart Study). Am J Cardiol, 99:1598-2.

Urao N, Okigaki M, Yamada H, et al. 2006. Erythropoietin-mobilized endothelial progenitors enhance reendothelialization via Akt-endothelial nitric oxide synthase activation and prevent neointimal hyperplasia. Circ Res, 98:1405-3.

Valgimigli M, Rigolin GM, Fucili A, et al. 2004. CD34+ and endothelial progenitor cells in patients with various degrees of congestive heart failure. Circulation, 110:1209-2.

Vasa M, Fichtlscherer S, Adler K, et al. 2001. Increase in circulating endothelial progenitor cells by statin therapy in patients with stable coronary artery disease. Circulation, 103:2885-90.

Vasa M, Fichtlscherer S, Aicher A, et al. 2001.Number and migratory activity of circulating endothelial progenitor cells inversely correlate with risk factors for coronary artery disease. Circ Res, 89(1):E1-7.

Virchow R. 1858. Cellular pathology. As based upon physiological and pathological histology. Lecture XVI-Atheromatous affection of arteries. London: John Churchill Editors.

Wang CH, Ciliberti N, Li SH, et al. 2004. Rosiglitazone facilitates angiogenic progenitor cell differentiation toward endothelial lineage: a new paradigm in glitazone pleiotropy. Circulation, 109:1392-400.

Wang CH, Verma S, Hsieh IC, et al. 2006. Enalapril increases ischemiainduced endothelial progenitor cell mobilization through manipulation of the CD26 system. J Mol Cell Cardiol, 41:34-3.

Wang CH, Ting MK, Verma S, et al. 2006. Pioglitazone increases the numbers and improves the functional capacity of endothelial progenitor cells in patients with diabetes mellitus. Am Heart J, 152:e1-8.
Weber C. 2005. Platelets and chemokines in atherosclerosis: partners in crime. Circ Res, 96:612-16.

Werner C, Kamani CH, Gensch C, et al. 2007. The peroxisome proliferatoractivated receptor-gamma agonist pioglitazone increases number and function of endothelial progenitor cells in patients with coronary artery disease and normal glucose tolerance. Diabetes, 56:2609-5.

Wilson PW, Nam BH, Pencina M, et al. 2005. C-reactive protein and risk of cardiovascular disease in men and women from the Framingham Heart Study. Arch Intern Med, 165:2473-8.

Xiao Q, Kiechl S, Patel S, et al. 2007. Endothelial progenitor cells, cardiovascular risk factors, cytokine levels and atherosclerosis - results from a large population-based study. PLoS ONE, 2:e975.

Yin Y, Huang L, Zhao X, et al. 2007. AMD3100 mobilizes endothelial progenitor cells in mice, but inhibits its biological functions by blocking an autocrine/paracrine regulatory loop of stromal cell derived factor- 1 in vitro. J Cardiovasc Pharmacol, 50:61-7.

Zeisberg EM, Tarnavski O, Zeisberg M, et al. 2007. Endothelial to mesenchymal transition contributes to cardiac fibrosis. Nat Med, 13:952-1.

Zernecke A, Bot I, Talab YD, et al. 2008. Protective role of CXC receptor 4/CXC ligand 12 unveils the importance of neutrophils in atherosclerosis. Circ Res, 102:209-17.

Zhao FH, Chen YD, Jin ZN, et al. 2008. Are impaired endothelial progenitor cells involved in the processes of late in-stent thrombosis and re-endothelization of drug-eluting stents? Med Hypotheses, 70:512-14.

Zhang H, Vakil V, Braunstein M, et al. 2007. Circulating endothelial progenitor cells in multiple myeloma: implications and significance. Blood, 105:3286-4.

Zohlnhöfer D, Ott I, Mehilli J, et al. 2006. Stem cell mobilization by granulocyte colony-stimulating factor in patients with acute myocardial infarction: a randomized controlled trial. JAMA, 295:1003-10. 
